\title{
Assessing PCR Inhibition from Humic Substances
}

\author{
Carney D. Matheson ${ }^{1, *}$, Carli Gurney ${ }^{2}$, Neal Esau $^{3}$ and Ryan Lehto ${ }^{4}$ \\ ${ }^{1}$ Department of Anthropology, Department of Biology, Lakehead University, Thunder Bay, P7B 5E1, Canada \\ ${ }^{2,3,4}$ Department of Biology, Lakehead University, Thunder Bay, P7B 5E1, Canada
}

\begin{abstract}
Inhibition remains the greatest methodological challenge in molecular analysis of buried biological remains. Inhibitory compounds associated with soil environments comprise primarily of humic acids and fulvic acids, collectively referred to as humic substances. We examined the sensitivity of 13 DNA polymerases to both humic acids $(11 \mathrm{ng}-110 \mu \mathrm{g})$ and fulvic acids $(9.4 \mathrm{ng}-94 \mu \mathrm{g})$ and the concentration at which successful amplification can be achieved. This research identified that all 13 DNA polymerases tested exhibited inhibition with varying concentrations of humic acids and that 5 out of the 13 DNA polymerase tested exhibited inhibition with varying concentrations of fulvic acid. The most tolerant DNA polymerase to inhibition due to the presence of humic and fulvic acids is $p f u$ DNA polymerase followed by KlenTaq ${ }^{\circledR}$ LA DNA polymerase and RealTaq DNA polymerase that were both only inhibited by $11 \mu \mathrm{g}$ and $110 \mu \mathrm{g}$ of humic acids. In addition, we present the use of size exclusion chromatography to remove small molecular weight humic substance, dramatically increasing the success of molecular analysis on material associated with burial. This research has implications to the fields of environmental microbiology, soil science, forensic science and archaeological science.
\end{abstract}

Keywords: Inhibition, PCR, Humic Substances, Size Exclusion Chromatography, Humic acids, Fulvic acids.

\section{INTRODUCTION}

Inhibition is only one of the problems facing the use of PCR amplification of DNA. The affects of inhibitory compounds on PCR is different depending on the inhibitory compound, the amplification conditions and the DNA polymerase being used [1-5]. Some substances will inhibit the enzymatic activity of the DNA polymerase while others will cause template inhibition. Template inhibition can be caused by the inhibiting substance binding to the template preventing it from being amplified. It has been indicated that humic substances can produce both types of inhibition $[2,5]$. The compounds causing this inhibition are dependent on the source of the biological material. Humic substances are primarily the cause for inhibition when extracting DNA from soil or buried biological remains [1, 4-6]. Thus the inhibition from humic substances is cause for concern in the fields of environmental microbiology, soil science, forensic science and archaeological science. Here we present the differences observed from the inhibition of humic and fulvic acids on 13 DNA polymerases.

Humic substances are amorphous, dark-coloured organic compounds which are relatively resistant to chemical and biological degradation [6,7]. The true nature of the dark brown and black substances formed by the decomposition of organic matter in the soil, and grouped together under the collective name humus, has long been a problem to both chemist and biologist, owing to the fact that the composition of these substances varies not only with the nature of the humus-producing materials, but also with temperature, moisture and pressure, and the methods of extraction [8].

\footnotetext{
*Address correspondence to this author at the Department of Anthropology, Lakehead University, Thunder Bay, P7B 5E1, Canada;

Tel: +1 807-343 8743; Fax: +1 807-343-8521;

E-mail: carney.matheson@lakeheadu.ca
}

Oxidative coupling of phenols is a significant reaction in the for mation of humic structures in the soil [9]. These substances are endowed with hormone-like activity that improves plant nutrition and growth $[10,11]$. Humic substances can make up $5.0-7.63 \mathrm{mg} / \mathrm{g}$ of soil but this is all dependent on the soil type [1]. Humic acids (HAs) comprise one of the major fractions of humic substances [11]. They are characterised by dark-coloured, alkali-soluble, acid-insoluble, and high molecular weight organic matter [7, 11]. Fulvic acids are another major fractions of humic substances [6]. These are characterised by light brown, water soluble compounds [6]. The capacity for soil to protect organic structures relies on the mineral composition of the soil, and predominantly involves weak non-covalent interactions between mineral surfaces and organic molecules [9]. According to Piccolo [12] and Booth et al. [9], protection can also occur within hydrophobic domains of humic substances. The chemical properties that help to stabilise humic structures include covalent bonding within, and non-covalent interactions between, structural units [9].

The failure of PCR reactions using soil and sediment DNA samples has usually been ascribed to inhibition by a brown substance contaminating DNA preparations $[6,13-$ 16]. The inhibition of PCR when amplifying DNA from the soil has also been ascribed to humic substances [4-6, 13-22]. Approximately $0.7-3.3 \mu \mathrm{g} / \mu \mathrm{L}$ of humic acids can be recovered in DNA extracted from soils depending on the type of soil and this represents $0.21-0.99 \%$ of total humc acids in the soil [1]. This inhibitor is difficult to remove using standard DNA purification procedures, and appeared to be universally present in organic soils and sediments [6]. Tsai and Olsen [20] observed that their standard PCR reaction was inhibited by the addition of as little as 10ng of humic acid [6]. Tebbe and Vahjen [1] found a similar degree of inhibition using commercial humic acid, and also showed that the brown in- 
hibitor from soil co-migrated with humic acid on agarose gels [6]. Sutlovic et al. [4] measured the inhibition that humic substances produced in ancient bone samples by real time PCR. The two mechanisms that have been considered is template cross-linking and enzymatic inhibition $[2,5]$. While the inhibition of the PCR by template cross-linking is easily understood, the mechanism of enzymatic inhibition by humic substances remain unknown, due to the amorphic nature of humic substances [5, 18-19, 23].

Some DNA polymerases have a greater tolerance for inhibition. Recently, genetically engineered DNA polymerases have been shown to tolerate high concentrations of inhibitors [24]. Kermekchiev et al. [24] has not only identified that KlenTaq ${ }^{\circledR}$ DNA polymerase (Sigma) has a high tolerance for inhibition found in DNA extractions from blood and soil but has also identified the specific regions of the enzyme that has lead to this increase tolerance. It was shown to be a N-terminal deletion of 278 amino acids along with some other polymorphisms [24]. Eilert et al. [3] has shown that some DNA polymerases from $T$. aquaticus and other species can have a greater tolerance for inhibitory substances including humic acids.

The most common method used to overcome PCR inhibition by humic substances is to dilute the extract. By diluting the extract the concentration of the inhibitory compounds is reduced to a level where inhibition no longer occurs. Alternatively many chemists and biologists use more robust extraction methods that are able to remove these humic substances more often however there is not one extraction method that removes them entirely. Due to the amorphous nature of the humic substances there is not one purification method that can reliably remove these substances either. Dilution of the extract will also reduce the concentration of DNA which reduces the efficiency of PCR amplification. The PCR amplification success might be sporadic or less amplified product being generated. Alternatively adding more DNA polymerase can overcome the inhibition of humic substances [4]. Other methods that have been used to remove humic substance from DNA extracts to prevent PCR inhibition, these include gel electrophoresis [25, 26], size exclusion chromatography [20,27], gel filtration chromatography [20, 27-28], chelation by proteins (like BSA) [29], chelation by EDTA [6], chelation with polyvinylpolypyrrolidone [17]. We propose a combination of size exclusion chromatography and gel filtration chromatography as a method to overcome this type of inhibition. Size exclusion chromatography was used here to remove the humic substance to demonstrate the removal of inhibition by removal of the humic substance. Size exclusion chromatography has also been used to remove metal ion inhibition in buried biological remains [30].

\section{MATERIALS AND METHODS}

\section{Humic Substances}

Humic substances were extracted from peat samples. These were collected from a peat bog (GG3) near Uppsala, Ontario from a commercial harvesting operation from a depth of 1.5 meters. The samples were air dried at room temperature in a fume hood. The large particles were removed and the dried peat sample was passed through a $2.0 \mathrm{~mm}$ sieve. Peat was then crushed with mortar and pestle to a fine powder. 10 grams of the fine powder were weighed and placed into a $200 \mathrm{~mL}$ flask. The sample was equilibrated to a $\mathrm{pH} 1.0$ with $1 \mathrm{M} \mathrm{HCl}$ and made up to a final volume of $100 \mathrm{~mL}$ at room temperature $(10 \mathrm{~mL}$ liquid/1g dry sample). The suspension was shaken for 1 hour and then separated by decantation after low speed centrifugation. The supernatant is retained for further processing (fulvic acid fraction 1).

The remaining pellet was neutralised with $1 \mathrm{M} \mathrm{NaOH}$ to pH7.0 then $0.1 \mathrm{M} \mathrm{NaOH}$ was added under an atmosphere of $\mathrm{N}_{2}$ to give a final extract to soil ratio of $10: 1$ and resuspended under $\mathrm{N}_{2}$ with intermittent shaking for 12 hours. The alkaline suspension was allowed to settle overnight and the supernatant collected by means of decantation after centrifugation. The supernatant was acidified with $6 \mathrm{M} \mathrm{HCl}$ with constant stirring to $\mathrm{pH} 1.0$ and then allowed the settle for 16 hours. The supernatant was removed after centrifugation (fulvic acid fraction 2). The pellet (humic acids) was dried in an oven at $25^{\circ} \mathrm{C}$ ready for use. The two fulvic acids fractions were combined and dried in an oven set to $25^{\circ} \mathrm{C}$.

A concentration gradient was prepared from the extracted humic and fulvic acids. The humic acid solution consists of $0.11 \mathrm{~g}$ of humic acids mixed with $1.0 \mathrm{~mL}$ of $\mathrm{ddH}_{2} \mathrm{O}$. The fulvic acid solution consists of 0.94 grams of fulvic acids dissolved in $10 \mathrm{~mL}$ of $\mathrm{ddH}_{2} \mathrm{O}$. A series dilution was performed to generate five humic acids solutions these were $1.1 \times 10^{-1} \mathrm{~g} / \mathrm{mL}, 1.1 \times 10^{-2} \mathrm{~g} / \mathrm{mL}, 1.1 \times 10^{-3} \mathrm{~g} / \mathrm{mL}, 1.1 \times 10^{-4} \mathrm{~g} / \mathrm{mL}$ and $1.1 \times 10^{-5} \mathrm{~g} / \mathrm{mL}$. While the five fulvic acids solutions were $9.4 \times 10^{-2} \mathrm{~g} / \mathrm{mL}, 9.4 \times 10^{-3} \mathrm{~g} / \mathrm{mL}, 9.4 \times 10^{-4} \mathrm{~g} / \mathrm{mL}, 9.4 \times 10^{-5} \mathrm{~g} / \mathrm{mL}$ and $9.4 \times 10^{-6} \mathrm{~g} / \mathrm{mL}$ also generated by serial dilution. The concentration of humic substances in the soil varies according to the type of soil. Humic substances have been shown to be in the milligram range [31,32]. The final amounts tested here range from $110 \mu \mathrm{g}$ to $11 \mathrm{ng}$ of humic acids and $94 \mu \mathrm{g}$ to $9.4 \mathrm{ng}$ of fulvic acids encompassing the range of humic substances that could be extracted from the soil and comparable to previous work by Tebbe and Vahjen [1].

\section{DNA Amplification}

The inhibition study examined the effect that humic acids and fulvic acids has on PCR amplification using 13 DNA polymerases. All reagents and reactions were prepared using sterile conditions and all reactions were optimised prior to use based on the supplier's instructions. Each reaction was set up with a negative and positive control with the five different concentrations of humic substance added to the PCR in triplicate. All the amplifications were performed using human mtDNA as template and forward and reverse primers at the 5' nucleotide positions 14724 and 15149 respectively. This amplification generates a 425bp product. An Eppendorf Mastercycler gradient thermocycler was used for all experiments. The DNA polymerases and their reaction mixes can be found in Table 1. For the inhibition studies $1 \mu \mathrm{L}$ of the humic substances solutions were added to the PCR reactions. All PCR amplifications were performed at $10 \mu \mathrm{L}$ total volume. All of the PCR amplification conditions for the DNA polymerases (except Phire ${ }^{\mathrm{TM}}$ Hot Start DNA polymerase, Vent $_{R}{ }^{\mathrm{TM}}$ DNA polymerase and Deep Vent ${ }_{R}^{\mathrm{TM}}$ DNA polymerase) have an initial denaturation $94^{\circ} \mathrm{C}$ for 2 minutes followed by 24 cycles of denaturation $94^{\circ} \mathrm{C}$ for 30 seconds, annealing $50^{\circ} \mathrm{C}$ for 1 minute and extension for 1 minute with a final hold at $4^{\circ} \mathrm{C}$. The conditions for Phire ${ }^{\mathrm{TM}}$ Hot Start DNA 
Table 1. The DNA Polymerases and Their Reaction Mixtures

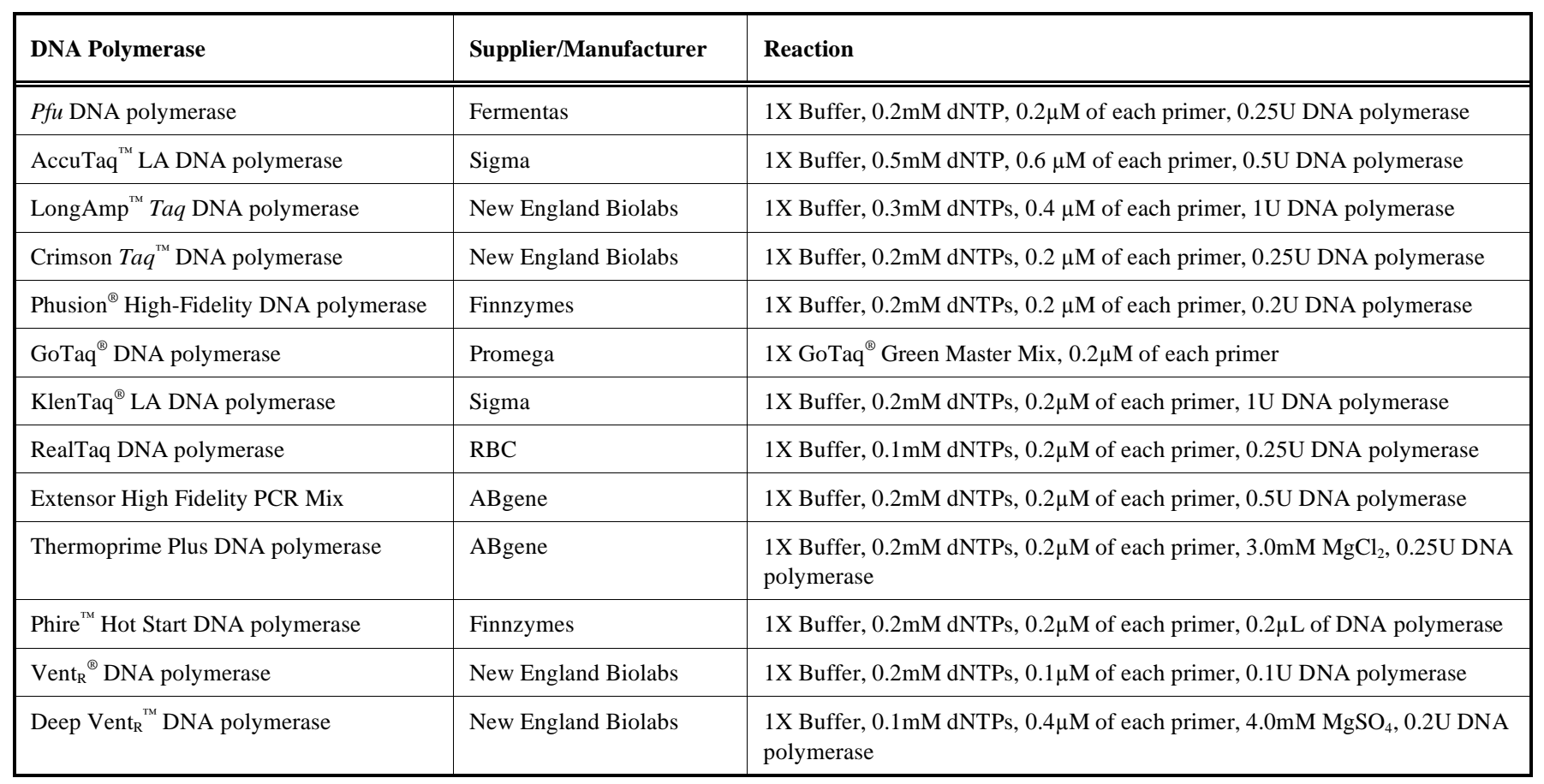

polymerase begin with an initial cycle at $98^{\circ} \mathrm{C}$ for $30 \mathrm{sec}-$ onds followed by 25 cycles of denaturing at $98^{\circ} \mathrm{C}$ for $5 \mathrm{sec}$ onds, annealing at $50^{\circ} \mathrm{C}$ and extending at $72^{\circ} \mathrm{C}$, a final extension runs at $72^{\circ} \mathrm{C}$ for 1 minute and then holds at $4^{\circ} \mathrm{C}$. The conditions for Vent ${ }_{R}{ }^{\mathrm{TM}}$ DNA polymerase begin with an initial cycle at $94^{\circ} \mathrm{C}$ for 2 minutes followed by 24 cycles that denature at $94^{\circ} \mathrm{C}$ for 30 seconds, anneal at $60^{\circ} \mathrm{C}$ for 30 seconds and extend at $72^{\circ} \mathrm{C}$ for 1 minute with a final extension at $72^{\circ} \mathrm{C}$ for 1 minute and hold at $4^{\circ} \mathrm{C}$. The cycling conditions for Deep Vent ${ }_{R}{ }^{\mathrm{TM}}$ DNA polymerase begins with an initial denaturation at $95^{\circ} \mathrm{C}$ for 3 minutes followed by 24 cycles that denature at $95^{\circ} \mathrm{C}$ for 30 seconds, anneal at $60^{\circ} \mathrm{C}$ for 30 seconds and extend at $72^{\circ} \mathrm{C}$ for 1 minute with a final extension at $72^{\circ} \mathrm{C}$ for 5 minute and hold at $4^{\circ} \mathrm{C}$.

The amplified products were analysed by $1 \%$ agarose gel electrophoresis using a $1 \mathrm{X}$ TBE run buffer. The agarose gels were stained with ethidium bromide and $3 \mu \mathrm{L}$ of a $100 \mathrm{bp}$ DNA ladder (Fermentas) was used for size comparison. Each well contained of $3 \mu \mathrm{L}$ of loading dye combined with $5 \mu \mathrm{L}$ of amplified product. The gels are run at 110 volts for approximately 1 hour.

\section{Size Exclusion Chromatography}

BioSpin P30 (BIORAD) size exclusion chromatography columns were used as an additional purification. BioSpin P30 (BIORAD) size exclusion chromatography columns are designed to remove small molecules. Occasionally two BioSpin P30 chromatography column purifications may be necessary to remove the visual discoloration (e.g. brown pigmentation) of the samples because the concentration of the humic substances exceeds the binding capacity of the column. The size exclusion chromatography purification protocol followed the recommended procedure by the manufacturer to ensure comparability of results. BioSpin P30 columns were autoclaved prior to use.

\section{Assessment of Inhibition}

The inhibition by humic substances was determined by using humic acid and fulvic acid extracts. A concentration series of these substances were added to an optimised PCR to determine at what concentration PCR failure may have occurred. This PCR failure was correlated to the degree of inhibition of that substance to a variety of DNA polymerases. The failure of the PCR was determined through gel electrophoresis.

\section{RESULTS}

The inhibition study using humic acids (Table 2) resulted in PCR inhibition, for all DNA polymerases studied, at the highest concentrations of $110 \mu \mathrm{g}$ of humic acids. The fulvic acid inhibition study (Table 3 ) resulted in variable PCR inhibition and amplification across the 13 different DNA polymerases. The gel electrophoresis most reliably detected full inhibition and no inhibition (Figs. 1 and 2). While most of the PCRs showed inhibition at the higher concentrations of humic acids (example Fig. 1) most showed no inhibition of fulvic acids at any concentration (example Fig 2). The use of size exclusion chromatography removed the majority of humic substances to allow successful amplification. However the amount of humic substances removed was dependant on the binding capacity of the column in which using two columns removed more of the inhibiting substances. The use of one size exclusion chromatography column efficiently removed enough humic substances to observe a 100 to 1000 fold difference in humic substance concentrations. The PCRs containing Deep Vent ${ }_{R}{ }^{\mathrm{TM}}$ DNA polymerase produced positive amplifications with between 11ng and 110ng of humic acids and between 9.4ng and 940ng of fulvic acids using the size exclusion chromatography, a result that was previously inhibited at all concentrations tested without the size exclusion chromatography (Fig. 3). 
Table 2. The Results of the Humic Acid Inhibition Study on the DNA Polymerases

\begin{tabular}{|c|c|c|c|c|c|c|}
\hline DNA Polymerase & Species & $11 n g$ & $110 \mathrm{ng}$ & $1.1 \mu \mathrm{g}$ & $11 \mu \mathrm{g}$ & $110 \mu \mathrm{g}$ \\
\hline$P f u$ DNA polymerase & Pfu & $+/+/+$ & $+/+/+$ & $+/+/+$ & $+/+/+$ & $-/-/-$ \\
\hline AccuTaq $^{\mathrm{TM}}$ LA DNA polymerase ${ }^{a}$ & Taq & $+/+/+$ & $+/-/+$ & $-1-1-$ & $-1-1-$ & $-/-/-$ \\
\hline LongAmp $^{\text {тм }}$ Taq DNA polymerase ${ }^{b}$ & Taq, Pyrococcus sp. GB-D & $+/+/+$ & $+/+/+$ & $-1-1-$ & $-1-1-$ & $-/-/-$ \\
\hline Crimson $\operatorname{Taq}^{\mathrm{TM}}$ DNA polymerase ${ }^{b}$ & Taq, Pyrococcus sp. GB-D & $+/+/+$ & $+/+/+$ & $+/+/+$ & $+/+/+$ & $-/-/-$ \\
\hline Phusion ${ }^{\circledR}$ High-Fidelity DNA polymerase & Engineered Taq & $+/+/+$ & $+/+/+$ & $-1-1-$ & $-1-/-$ & $-/-/-$ \\
\hline GoTaq ${ }^{\circledR}$ DNA polymerase & Taq & $+/+/+$ & $+/+/-$ & $-1-/-$ & $-1-1-$ & $-/-/-$ \\
\hline KlenTaq ${ }^{\circledR}$ LA DNA polymerase & Taq & $+/+/+$ & $+/+/+$ & $+/+/+$ & $-/-/-$ & $-/-/-$ \\
\hline RealTaq DNA polymerase & Thermus sp. & $+/+/+$ & $+/+/+$ & $+/+/+$ & $-/-/-$ & $-/-/-$ \\
\hline Extensor Hi-Fidelity PCR mix ${ }^{c}$ & Taq & $\mathrm{P} /-/ \mathrm{P}$ & $-1-1-$ & $-1-1-$ & $-1-1-$ & $-/-/-$ \\
\hline Thermoprime Plus DNA polymerase & Taq & $+/+/+$ & $+/+/+$ & $-/-/-$ & $-1-1-$ & $-1-/-$ \\
\hline Phire $^{\mathrm{TM}}$ Hot Start DNA polymerase & Taq & $-/-/+$ & $+/+/+$ & $-1-/-$ & $-1-/-$ & $-/-/-$ \\
\hline Vent $_{\mathrm{R}}{ }^{\circledR}$ DNA polymerase & $T l i$ & $+/+/+$ & $+/+/-$ & $-/-/-$ & $-/-/-$ & $-/-/-$ \\
\hline Deep Vent ${ }_{R}{ }^{\mathrm{TM}}$ DNA polymerase & Pyrococcus sp. GB-D & $-/-/-$ & $-/-/-$ & $\mathrm{P} /-/-$ & $-1-/-$ & $-/-/-$ \\
\hline
\end{tabular}

${ }^{a}$ Mixture of Taq DNA polymerase and a proprietary proof-reading enzyme.

${ }^{b}$ Mixture of Taq DNA polymerase and Deep Vent ${ }_{\mathrm{R}}^{\circledR}$ DNA Polymerases.

${ }^{c}$ Mixture of Thermoprime Plus DNA Polymerase and a proprietary proof-reading enzyme.

+ Indicates the band was present on the gel with a similar intensity to the amplification control.

- Indicates inhibition, no band was present on the gel.

P Partial inhibition indicates that there was a feint band on the gel, weaker than the amplification control.

Experiments performed in triplicate.

Table 3. The Results of the Fulvic Acid Inhibition Study on the DNA Polymerases

\begin{tabular}{|c|c|c|c|c|c|c|}
\hline DNA Polymerase & Species & $9.4 n g$ & 94ng & $940 \mu \mathrm{g}$ & $9.4 \mu \mathrm{g}$ & $94 \mu \mathrm{g}$ \\
\hline$P f u$ DNA polymerase & Pfu & $+/+/+$ & $+/+/+$ & $+/+/+$ & $+/+/+$ & $+/+/+$ \\
\hline AccuTaq $^{\mathrm{TM}}$ LA DNA polymerase ${ }^{a}$ & $T a q$ & $+/+/+$ & $+/+/+$ & $\mathrm{P} /+/ \mathrm{P}$ & $+/+/+$ & $+/+/+$ \\
\hline LongAmp $^{\mathrm{TM}} T a q$ DNA polymerase ${ }^{b}$ & Taq, Pyrococcus sp. GB-D & $-/-/-$ & $-/-/-$ & $-/-/-$ & $-/-/-$ & $-/-/-$ \\
\hline Crimson $\operatorname{Taq}^{\mathrm{TM}}$ DNA polymerase ${ }^{b}$ & Taq, Pyrococcus sp. GB-D & $-/-/-$ & $-/-/-$ & $-/-/-$ & $-/-/-$ & $-/-/-$ \\
\hline Phusion ${ }^{\circledR}$ High-Fidelity DNA polymerase & Engineered Taq & $+/+/+$ & $+/+/+$ & $+/+/+$ & $+/+/+$ & $+/+/+$ \\
\hline GoTaq $^{\circledR}$ DNA polymerase & $T a q$ & $+/+/+$ & $+/+/+$ & $+/+/+$ & $+/+/+$ & $+/+/+$ \\
\hline KlenTaq ${ }^{\circledR}$ LA DNA polymerase & Taq & $+/+/+$ & $+/+/+$ & $+/+/+$ & $+/+/+$ & $+/+/+$ \\
\hline RealTaq DNA polymerase & Thermus sp. & $+/+/+$ & $+/+/+$ & $+/ \mathrm{P} / \mathrm{P}$ & $\mathrm{P} / \mathrm{P} / \mathrm{P}$ & $\mathrm{P} /-/ \mathrm{P}$ \\
\hline Extensor Hi-Fidelity PCR mix ${ }^{c}$ & $T a q$ & $-1-1-$ & $-1-1-$ & $-1-1-$ & $-/-/-$ & $-1-/-$ \\
\hline Thermoprime Plus DNA polymerase & Taq & $+/+/+$ & $+/+/+$ & $+/+/+$ & $+/+/+$ & $+/+/+$ \\
\hline Phire ${ }^{\mathrm{TM}}$ Hot Start DNA polymerase & $T a q$ & $+/+/+$ & $\mathrm{P} / \mathrm{P} /+$ & $+/+/+$ & $+/+/+$ & $+/+/+$ \\
\hline Vent $_{R}{ }^{\circledR}$ DNA polymerase & $T l i$ & $+/+/+$ & $+/+/+$ & $+/+/+$ & $+/+/+$ & $+/+/+$ \\
\hline Deep Vent ${ }_{R}{ }^{\mathrm{TM}}$ DNA polymerase & Pyrococcus sp. GB-D & $+/+/-$ & $-/-/-$ & $+/-/-$ & $-/+/+$ & $-/-/-$ \\
\hline
\end{tabular}

${ }^{a}$ Mixture of Taq DNA polymerase and a proprietary proof-reading enzyme.

${ }^{b}$ Mixture of Taq DNA polymerase and Deep Vent ${ }_{\mathrm{R}}^{\circledR}$ DNA Polymerases.

${ }^{c}$ Mixture of Thermoprime Plus DNA Polymerase and a proprietary proof-reading enzyme.

+ Indicates the band was present on the gel with a similar intensity to the amplification control.

- Indicates inhibition, no band was present on the gel.

P Partial inhibition indicates that there was a feint band on the gel, weaker than the amplification control.

Experiments performed in triplicate. 


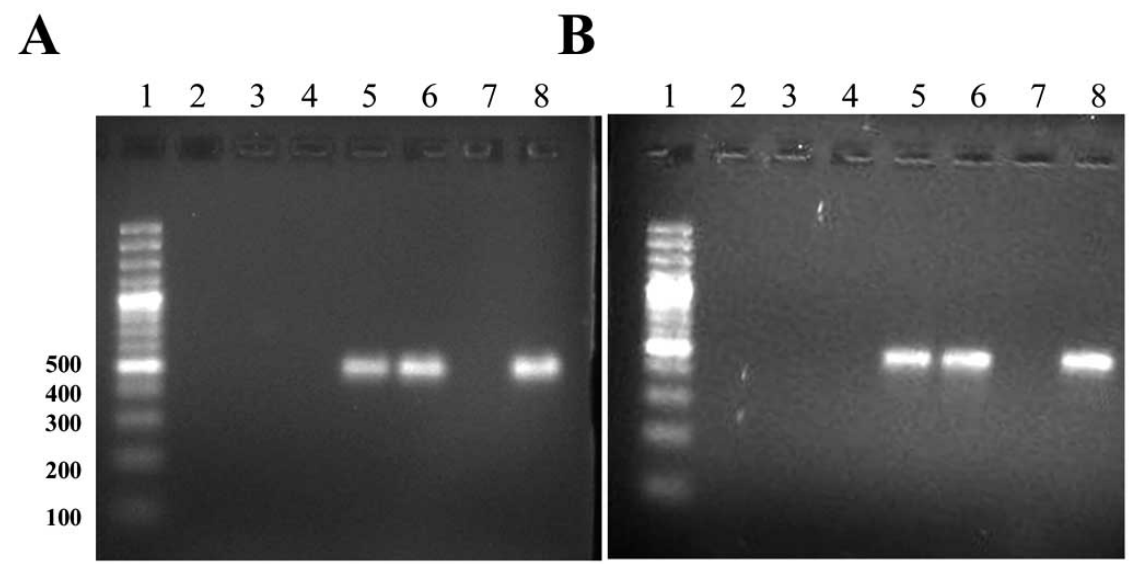

Fig. (1). Agarose gel electrophoresis examples of humic acid inhibition. Gel A is an example using LongAmp ${ }^{\mathrm{TM}}$ Taq DNA polymerase and Gel B is an example using Vent ${ }_{\mathrm{R}}^{\circledR}$ DNA polymerase. Both gels are set up with the same conditions in each lane; lane 1, 100bp DNA ladder; lane 2, Amplification spiked with 11ng of humic acids; lane 3, Amplification spiked with 110ng of humic acids; lane 4, Amplification spiked with $1.1 \mu \mathrm{g}$ of humic acids; lane 5, Amplification spiked with $11 \mu \mathrm{g}$ of humic acids; lane 6 , Amplification spiked with $110 \mu \mathrm{g}$ of humic acids; lane 7, negative PCR control; and lane 8, positive control.

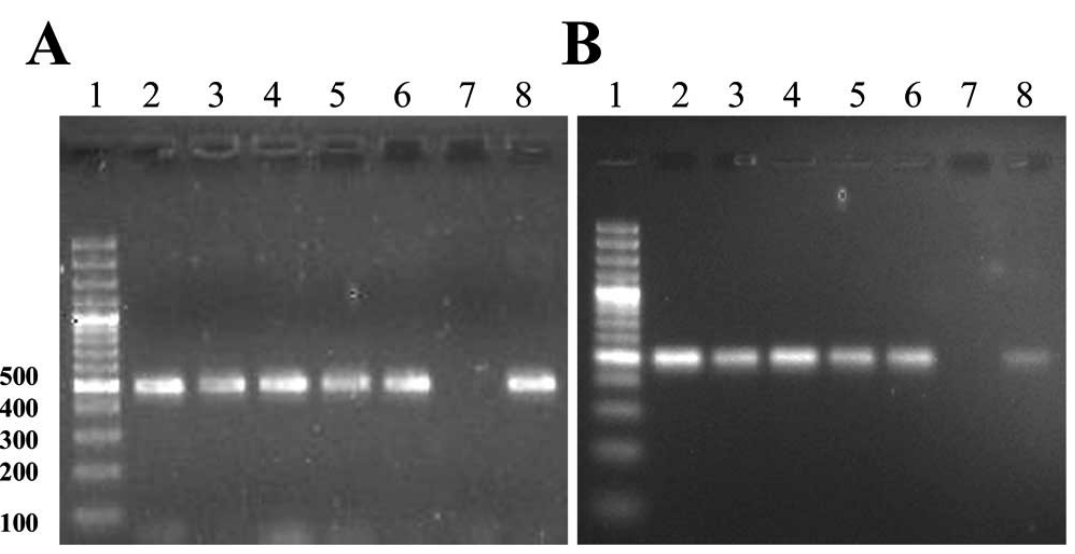

Fig. (2). Agarose gel electrophoresis examples of fulvic acid inhibition. Gel A is an example using Phusion ${ }^{\circledR}$ High-Fidelity DNA polymerase and Gel B is an example using Pfu DNA polymerase. Both gels are set up with the same conditions in each lane; lane 1, 100bp DNA ladder; lane 2, Amplification spiked with 9.4ng of fulvic acids; lane 3, Amplification spiked with 94ng of fulvic acids; lane 4, Amplification spiked with 940ng of fulvic acids; lane 5, Amplification spiked with $9.4 \mu \mathrm{g}$ of fulvic acids; lane 6 , Amplification spiked with $94 \mu \mathrm{g}$ of fulvic acids; lane 7, negative PCR control; and lane 8, positive control.

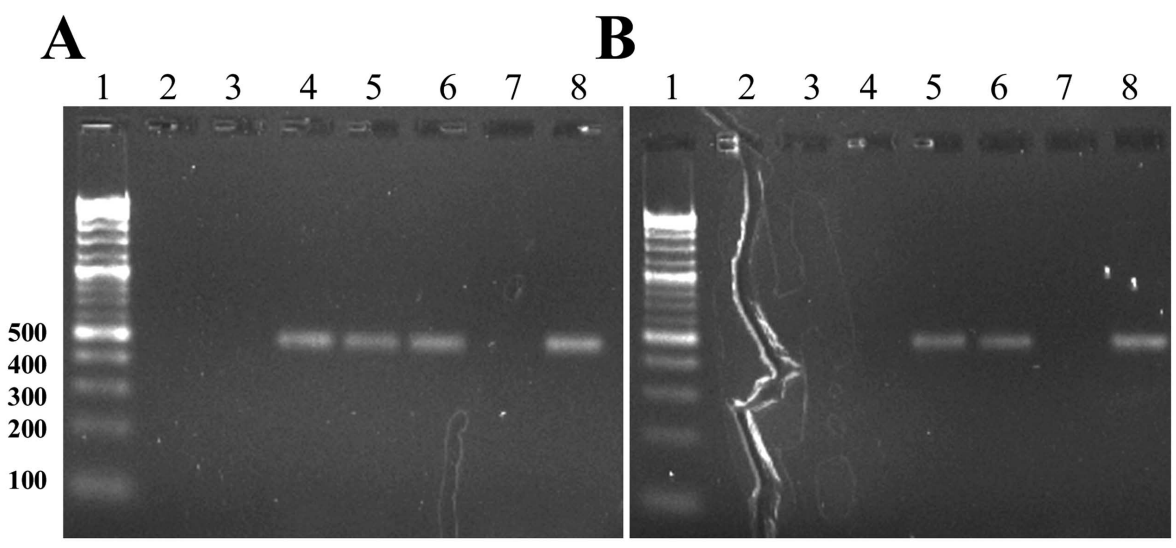

Fig. (3). Gel electrophoresis examples of the efficiency of the size exclusion chromatography in removing some of the inhibition by humic acids (Gel A) and fulvic acids (Gel B) from amplification with Deep Vent ${ }_{\mathrm{R}}{ }^{\mathrm{T}}$ DNA polymerase. Gel A: lane 1, 100bp DNA ladder; lane 2, Amplification spiked with 11ng of humic acids; lane 3, Amplification spiked with 110ng of humic acids; lane 4, Amplification spiked with $1.1 \mu \mathrm{g}$ of humic acids; lane 5, Amplification spiked with $11 \mu \mathrm{g}$ of humic acids; lane 6 , Amplification spiked with $110 \mu \mathrm{g}$ of humic acids; lane 7, negative PCR control; and lane 8, positive control. Gel B: lane 1, 100bp DNA ladder; lane 2, Amplification spiked with 9.4ng of fulvic acids; lane 3, Amplification spiked with 94ng of fulvic acids; lane 4, Amplification spiked with 940ng of fulvic acids; lane 5, Amplification spiked with $9.4 \mu \mathrm{g}$ of fulvic acids; lane 6 , Amplification spiked with $94 \mu \mathrm{g}$ of fulvic acids; lane 7 , negative PCR control; and lane 8 , positive control. 


\section{DISCUSSION}

Humic substances are one of the biggest problems faced when extracting DNA from biological material recovered from the soil. The results of the inhibitory affects of humic acids in this research indicate that all of the PCRs and respective DNA polymerases have a tolerance threshold at $110 \mu \mathrm{g}$ of humic acids. The failure of the PCRs could be due to enzymatic inhibition of the respective DNA polymerases, it could represent the concentration at which the binding of humic acids to the DNA template becomes ubiquitous preventing any template from being amplified or a combination of both. However some of the DNA polymerases (Extensor Hi-Fidelity DNA polymerase, Phire ${ }^{\mathrm{TM}}$ Hot Start DNA polymerase and Deep Vent ${ }_{\mathrm{R}}{ }^{\mathrm{TM}}$ DNA polymerases) are intolerant to humic acids at all concentrations tested suggesting both mechanisms may be present in the PCR. There are currently such a diverse range of DNA polymerases available that it is difficult to identify which DNA polymerases might be adversely affected by the presence of humic substances. Many researchers [1, 4-5, 15, 18, 20, 23-24, 27-29, 33] have shown that different $T a q$ DNA polymerases are sensitive to humic substances while Kermekchiev et al. [24] showed some Taq DNA polymerases and some engineered Taq DNA polymerases have been highly resistant to the affects of humic acids. The research presented here reflects the same trend with variation between the different Taq DNA polymerases. Kermekchiev et al. [24] has also shown that other non-Taq species of DNA polymerases are less affected by humic acids as has this research with $p f u$ DNA polymerase but some pyrococcus species DNA polymerases do not share the same degree of tolerance like the Deep $\mathrm{Vent}_{\mathrm{R}}{ }^{\mathrm{T}}$ DNA polymerase. There has been very little research that has isolated fulvic acids to determine the contribution to humic substance inhibition they provide. The outcome indicates that DNA polymerases are more tolerant of fulvic acids than humic acids. However there was the same variability between the DNA polymerases affected by fulvic acids. Three of the DNA polymerases (LongAmp ${ }^{\mathrm{TM}}$ Taq DNA polymerase, Crimson $\mathrm{Taq}^{\mathrm{TM}}$ DNA polymerase and Extensor Hi-Fidelity DNA polymerase) were inhibited by fulvic acid at every concentration while all of the PCRs using the other enzymes showed no inhibition at any of the concentrations tested.

Overall the DNA polymerase least affected by inhibition from humic and fulvic acids is $p f u$ DNA polymerase, suggesting there might be a greater tolerance in the DNA polymerases of this species, followed by KlenTaq ${ }^{\circledR}$ LA DNA polymerase and RealTaq DNA polymerase. Some of the polymerases were inhibited by one humic substance and not the other (only humic acids - Phire ${ }^{\mathrm{TM}}$ Hot Start DNA polymerase). The blended DNA polymerases were varied and most likely dependant on each of the enzymes used in the mixture. One of the least successful DNA polymerases was the Extensor Hi-Fidelity DNA polymerase this is a blended DNA polymerase containing Thermoprime Plus DNA Polymerase and a proprietary proof- Reading enzyme. Thermoprime Plus DNA Polymerase was tested on its own and performed generally the same as the Taq DNA polymerases so the failure observed in the Extensor Hi-Fidelity DNA polymerase mixture could be due to the second enzyme in the mixture or the amount of template inhibition that might have been present. The two DNA polymerases that were the most sensitive to the inhibitory compounds were Extensor Hi-Fidelity DNA polymerase and Deep Vent ${ }_{\mathrm{R}}{ }^{\mathrm{TM}}$ DNA polymerase which were inhibited at every concentration with both humic and fulvic acids (excluding the sporadic success of Deep Vent ${ }_{R}{ }^{\mathrm{TM}}$ DNA polymerase). However all of the DNA polymerases tested produced better results after size exclusion chromatography.

The removal of humic substances and subsequent successful PCR amplification was achieved with size exclusion chromatography. This research supports previous research by Miller [27] and Tsai and Olsen [20] on the removal of humic substances. Size exclusion chromatography column will trap small molecules within the gel beads allowing just the larger molecules to pass through which would include the DNA. Not all humic substances will consist of small molecules as humic acids are amorphous. So size exclusion chromatography simply removes a sufficient portion of the humic substances that would allow it to be amplified. Compared to the tradition method of simply diluting the extract to dilute out the inhibitor the removal of some of the inhibiting compounds would have a similar effect while retaining the same or very similar concentrations of DNA. Other methods like using a chelator (EDTA, BSA) can be an effective way of resolving the problem but the efficiency might vary between different DNA polymerases. Many manufacturers include BSA in their buffers for PCR which can aid in the amelioration of humic substance inhibition. Increasing the quantity of DNA polymerase can be more expensive depending on the DNA polymerase and can produce sporadic results. The purification with size exclusion chromatography allowed the amplification of a 100 to 1000 -fold increase in concentration of the humic substances by the removal of these substances to within ranges of DNA polymerase tolerance. This could be explained by three possibilities, 1) the larger humic substances that will not be removed by size exclusion are still present to inhibit the amplification, 2) the binding capacity of the size exclusion chromatography columns has been reached and a second purification with these columns will remove more humic substances to allow the amplification to be successful or 3) the inhibition is template inhibition, where the humic substance has bound to the template and cannot be removed by size exclusion chromatography.

Due to the amorphous nature and the size range of humic substances we propose that gel filtration chromatography and size exclusion chromatography can be used in conjunction with each other for a more reliable removal of humic substances. The gel filtration chromatography can be used to remove the larger humic substances as indicated by various researchers [20, 23, 27-28] as it filters the molecules by size allowing the smaller molecules to pass through the column faster. The gel filtration column allows the ability to recover any size molecules from the smaller molecules upwards by increasing either the speed or the time of centrifugation. In this application the larger molecules would be retained within the gel matrix of the column thus removing large humic substances. However the use of gel filtration may remove some of the large fragments of DNA but through controlled centrifugation this problem can be evaluated. While size exclusion chromatography can be used to remove the smaller humic substances by trapping small molecules 
within the gel beads allowing just the larger molecules to pass through including the DNA.

The limitations of this research are the use of gel electrophoresis as the detection system and the binding capacity of the size exclusion chromatography column. Gel electrophoresis can be reliably used to indicate full inhibition and very little or no inhibition but does not assess the degree of partial inhibition. The use of real time PCR would be more reliable for the identification the varying degree of partial inhibition [33]. While it is possible to remove both humic acids and fulvic acids using size exclusion chromatography columns the removal is constrained by the binding capacity of the column which will limit how much of the smaller humic substances are able to be removed, this can be overcome by running the sample through two size exclusion chromatography columns.

\section{CONCLUSIONS}

The inhibitory nature of humic substances on in vitro molecular analysis, specifically PCR amplification has been explored with 13 DNA polymerases. In addition this research uses both constituents of humic substances, humic acids and fulvic acids, extracted directly from soil material rather than synthetic sources providing a more reliable assessment. The results indicate that humic acids are far more of a concern than fulvic acids in regards to inhibition and that the effects on the PCRs of each of the DNA polymerases vary greatly. The DNA polymerase most tolerant of these inhibitory substances was the $P f u$ DNA polymerase. Klen$\mathrm{Taq}^{\circledR}$ LA DNA polymerase and RealTaq DNA polymerase were the next most tolerant enzymes against both fulvic and humic acids. Even though the PCR containing the Deep Vent $_{R}{ }^{\mathrm{TM}}$ DNA polymerase proved to be the most sensitive polymerase to these two substances the Deep Vent ${ }_{R}{ }^{\mathrm{TM}}$ DNA polymerase still has the highest temperature tolerance of all these enzymes. It must be noted that each of these enzyme are exceptional enzyme that have been designed and prepared for specific molecular uses and their sensitivity to humic and fulvic acids does not imply their sensitivity to other inhibitors or that they are less reliable enzymes. However for the extraction of DNA from soil bacteria or from buried biological remains this research may provide information for the researcher to determine which DNA polymerase might be the most appropriate. This research emphasises the importance of testing the preferred DNA polymerase with these humic substances to determine the inhibitory affect they may have in the PCR amplification. In addition this research provides the use of size exclusion chromatography as a method to purify extractions from buried biological material to specifically remove humic and fulvic acids.

\section{ACKNOWLEDGEMENTS}

The authors would like thank Christina Mol and Dr. Peter Lee for the peat bog sample for the acquisition of humic substances. We would also like to thank the International Humic Substance Society (http://ihss.gatech.edu/ihss2/) for the method of humic and fulvic acid extraction. Finally we would like to thank the following suppliers for DNA polymerase samples to optimize the experimental condition upon; Fermentas, Finnzymes, Promega, RBC, ABgene and Sigma.

\section{REFERENCES}

[1] Tebbe CC, Vahjen W. Interference of humic acids and DNA extracted directly from soil in detection and transformation of recombinant DNA from bacteria and a yeast. Appl Environ Microbiol 1993; 59: 2657-65.

[2] Opel KL, Chung D, McCord BR. A Study of PCR Inhibition Mechanisms Using Real Time PCR*. J Forensic Sci. 2009.

[3] Eilert KD, Foran DR. Polymerase resistance to polymerase chain reaction inhibitors in bone*. J Forensic Sci. 2009; 54: 1001-7.

[4] Sutlovic D, Definis GM, Andelinovic S, Gugic D, Primorac D. Taq polymerase reverses inhibition of quantitative real time polymerase chain reaction by humic acid. Croat Med J 2005; 46: 556-62.

[5] Sutlovic D, Gamulin S, Definis-Gojanovic M, Gugic D, Andjelinovic $\mathrm{S}$. Interaction of humic acids with human DNA: proposed mechanisms and kinetics. Electrophoresis 2008; 29: 1467-72.

[6] Watson RJ, Blackwell B. Purification and characterization of a common soil component which inhibits the polymerase chain reaction. Can J Microbiol 2000; 46: 633-42.

[7] Schnitzer M. Soil Organic Matter-The next 75 years. Soil Sci 1991; 151: 41-58.

[8] Bottomley WB. The Formation of Humic Bodies from Organic Substances. Biochem J 1915; 9: 260-8.

[9] Booth K, Patti A, Scott J, Wallis P. Organic matter transformation catalyzed by clays: model reactions for carbon sequestration in soils. In: Singh B, Eds Supersoil 2004. Proceedings of the 3rd Australian New Zealand Soils Conference; 2004; University of Sydney: The Regional Institute Ltd: 2004; pp. 1-7.

[10] Chen Y, Aviad T. Effects of humic substances on plant growth. In: MacCarthy CEC, P. Malcolm RL, Bloom PR, Eds. Humic substances in soil and crop sciences: selected readings : proceedings of a symposium cosponsored by the International Humic Substances Society 1990; Chicago, Illinois: American Society of Agronomy : Soil Science Society of America 1990; pp. 161-86.

[11] Canellas LP, Olivares FL, Okorokova-Facanha AL, Facanha AR Humic acids isolated from earthworm compost enhance root elongation, lateral root emergence, and plasma membrane H+-ATPase activity in maize roots. Plant Physiol 2002; 130: 1951-7.

[12] Piccolo A. The supramolecular structure of humic substances: A novel understanding of humus chemistry and implications in soil science. Advances in agronomy. Academic Press 2002: pp. 57-134.

[13] Torsvik VL. Isolation of bacterial DNA from soil. Soil Biol Biochem 1980; 12: 15-21.

[14] Tsai YL, Olson BH. Rapid method for direct extraction of DNA from soil and sediments. Appl Environ Microbiol 1991; 57: 10704.

[15] Bruce KD, Hiorns WD, Hobman JL, Osborn AM, Strike P, Ritchie DA. Amplification of DNA from native populations of soil bacteria by using the polymerase chain reaction. Appl Environ Microbiol 1992; 58: 3413-6.

[16] Romanowski G, Lorenz MG, Wackernagel W. Use of polymerase chain reaction and electroporation of Escherichia coli to monitor the persistence of extracellular plasmid DNA introduced into natural soils. Appl Environ Microbiol 1993; 59: 3438-46.

[17] Steffan RJ, Goksoyr J, Bej AK, Atlas RM. Recovery of DNA from soils and sediments. Appl Environ Microbiol 1988; 54: 2908-15.

[18] Porteous LA, Armstonrg JL, Seidler RJ, Watrud LS. An effective method to extract DNA from environmental samples for polymerase chain reaction amplification and DNA fingerprint analysis. Curr Microbiol 1994; 29: 301-7.

[19] Porteous LA, Armstrong JL. Recovery of bulk DNA from soil by a rapid, small-scale extraction method. Curr Microbiol 1991; 22: 345-8.

[20] Tsai YL, Olson BH. Rapid method for separation of bacterial DNA from humic substances in sediments for polymerase chain reaction. Appl Environ Microbiol 1992; 58: 2292-5.

[21] Jacobsen CS, Rasmussen RP. Development and application of a new method to extract bacterial DNA from soil based on separation of bacteria from soil with cation-exchange resin. Appl Environ Microbiol 1992; 58: 2458-62.

[22] Holben WE, Jansson JK, Chelm BK, Tiedje JM. DNA Probe Method for the Detection of Specific Microorganisms in the Soil Bacterial Community. Appl Environ Microbiol 1988; 54: 703-11.

[23] Porteous LA, Seidler RJ, Watrud LS. An improved method for purifying DNA from soil for polymerase chain reaction amplification and molecular ecology applications. Mol Ecol 1997; 6: 787-91. 
[24] Kermekchiev MB, Kirilova LI, Vail EE, Barnes WM. Mutants of Taq DNA polymerase resistant to PCR inhibitors allow DNA amplification from whole blood and crude soil samples. Nucleic Acids Res 2009; 37: e40.

[25] Moreira D. Efficient removal of PCR inhibitors using agaroseembedded DNA preparations. Nucleic Acids Res 1998; 26: 330910.

[26] Roh C, Villatte F, Kim BG, Schmid RD. "In-gel patch electrophoresis:" a new method for environmental DNA purification. Electrophoresis 2005; 26: 3055-61.

[27] Miller DN. Evaluation of gel filtration resins for the removal of PCR-inhibitory substances from soils and sediments. J Microbiol Methods 2001; 44: 49-58.

[28] Jackson CR, Harper JP, Willoughby D, Roden EE, Churchill PF. A simple, efficient method for the separation of humic substances and DNA from environmental samples. Appl Environ Microbiol 1997; 63: 4993-5.
[29] Kreader C. Relief of Amplification Inhibition in PCR with Bovine Serum Albumin or T4 Gene 32 Protein. Appl Environ Microbiol 1996; 62: 1102-6.

[30] Matheson CD, Marion TE, Hayter S, Esau N, Fratpietro R, Vernon KK. Technical note: Removal of metal ion inhibition encountered during DNA extraction and amplification of copper-preserved archaeological bone using size exclusion chromatography. Am J Phys Anthropol 2009; 140: 384-91.

[31] Pal S, Sengupta MB. Nature and properties of humic acid prepared from different sources and its effect on nutrient availability. Plant Soil 1985; 88: 71-91.

[32] Gondar D, López R, Fiol S, Antelo JM, Arce F. Effect of soil depth on acid properties of humic substances extracted from an ombrotrophic peat bog in northwest Spain. Eur J Soil Sci 2005; 56: 793-801.

[33] Opel KL, Chung D, McCord BR. A Study of PCR Inhibition Mechanisms Using Real Time PCR. J Forensic Sci 2010; 55: 25-3.

(C) Carney Matheson; Licensee Bentham Open.

This is an open access article licensed under the terms of the Creative Commons Attribution Non-Commercial License (http://creativecommons.org/licenses/ by-nc/3.0/) which permits unrestricted, non-commercial use, distribution and reproduction in any medium, provided the work is properly cited. 